\title{
The Impact of Policy Changes: The Opportunities of Community Renewable Energy Projects in the UK and the Barriers they Face
}

\section{Pegah Mirzania $^{a b^{*}}$, Andy Ford ${ }^{b}$, Deborah Andrews ${ }^{c}$, George Ofori ${ }^{b}$, Graeme Maidment ${ }^{\mathrm{c}}$}

a School of Water, Energy and Environment, Cranfield University, Cranfield, Bedfordshire MK43 0AL

b School of the Built Environment and Architecture, London South Bank University, SE1 OAA London, UK,

c School of Engineering, London South Bank University, SE1 OAA London, UK

\begin{abstract}
The UK's energy system is predominantly centralised with a major reliance on fossil fuels. The trilemma of successfully delivering energy security, equity, and environmental sustainability, whilst dealing with an ageing energy infrastructure, demands change within the entire energy system. In recent years, Community Renewable Energy (CRE) projects have played a significant role in the transition of the UK's energy system, but since 2016 government support for them has been less robust. This paper reports a web-based survey and semi-structured interviews of the UK's community energy groups undertaken between August 2016 and March 2017. The results indicate that huge problems have arisen due to the changes in government policy, particularly for solar photovoltaic schemes. The majority of CRE organisations have chosen to focus on managing their existing assets rather than plan further growth. Additionally, this paper highlights the key challenges facing CRE projects that wish to develop innovative business models under the new policy conditions.
\end{abstract}

Keywords: Community Renewable Energy (CRE); Business model; Feed -in-Tariff (FIT)

\section{Introduction}

The transition towards low-carbon and renewable energy has occurred simultaneously with the shift away from governance corporate utility, towards a more diverse mix of communities and citizen investors being involved in the generation of energy (Hall and Roelich, 2015). The participation of communities and individuals

\footnotetext{
${ }^{*}$ Corresponding Author current affiliation is School of Water, Energy and Environment, Cranfield University, Cranfield, Bedfordshire MK43 OAL
} 
in energy production and sustainable development has been a significant part of the UK's government approach towards a low-carbon future. One of the key points in the UK Low Carbon Transition Plan on National Strategy for Climate Change and Energy, published in 2009, was to support communities in their efforts to tackle climate change and to provide opportunities for them to develop innovative ideas and make knowledgeable decisions surrounding sustainable growth (HM Government, 2009). Community energy projects which aim to create more sustainable energy systems are an example of 'Community Innovation, 'which refers to a form of bottom-up or 'grassroots' innovation brought about by communities rather than the government or businesses (Tang et al., 2011).

Since 2010, several policies have explicitly aimed to provide support for CRE development in different regions across the UK. Examples of such regional Community Renewable Energy (CRE) support schemes include: the Welsh 2010 Ynni'r Fro programme (Gov.Wales, 2014); the Scottish 2011 Community and Renewable Energy Scheme; the 2012 England and Wales Local Energy Assessment Fund (Energy Saving Trust, 2012); the 2013 England Rural Community Energy Fund (DEFR, 2012); and the 2014 UK Community Energy Strategy and Urban Communities Energy Fund (Centre for Sustainable Energy, 2014; DECC, 2014). In addition, in 2010 the government's incentive scheme for promoting renewable energy was changed. Instead of providing capital grants, revenue payments specifically designed to foster CRE projects were offered, including the Feed-in-Tariff (FIT) and the Renewable Heat Incentive (RHI) (Gubbins, 2010).

However, compared to other European countries, growth in CRE projects has been disappointing in spite of this government support (Walker et al., 2007; Allen et al., 2012; Nolden, 2013a). It represented just under 0.4\% of the UK's renewable energy capacity by 2014, supplying the equivalent of only $~ 65.500$ homes (Harnmeijer, 2016). A number of reasons for this lack of progress have been suggested. Bolinger (2001) argues that there is little tradition of local cooperative organisation in the UK on which the CRE sector can draw. Walker (2008) and Nolden (2013a) observe that most of the UK's renewable energy policies have not been conducive to CRE development, favouring the development of centralised, large-scale projects undertaken by corporate utilities, rather than more modest local initiatives. Johnson et al. (2014) add that the UK's centralised banking structure and energy system mean that CRE projects have to overcome huge financial and bureaucratic barriers to growth, and Martiskainen (2014) points out that many government-funded schemes for community energy have tended to be start-stop in nature. 
On $27^{\text {th }}$ January 2014, the UK government published the first ever Community Energy Strategy and highlighted the effectiveness of community-led action in tackling the challenges facing the UK energy system. The Strategy stated that community-led action 'can often tackle challenges more effectively than government alone, developing solutions to meet local needs, and involving local people'(DECC, 2014,pp7). However, more recent community energy policy in the UK appears to be inconsistent with this stated aspiration. Only a year later, the closure of many key renewable support mechanisms was being announced: the Renewable Obligation (RO) for new onshore wind was ended a year earlier than originally planned (DECC, 2015a); most of the government stake in the Green Investment Bank was sold off (Environmental Audit Committee, 2015); the termination of Green Deal Communities was announced (DECC, 2015d); CRE projects were excluded from the Enterprise Investment Tax Relief Scheme (HM Revenue and Customs, 2015); and onshore wind was excluded from a second auction of the Contract for Difference (DECC, 2015c).

The final and most decisive U-turn in 2015 was the removal of pre-accreditation and pre-registration for FIT on 17 December, along with a major reduction in the FIT generation rate (DECC, 2015e), a move that dramatically affected the renewable energy industry in general and the CRE sector in particular. Prior to these changes, the FIT scheme had been proving a most effective incentive, encouraging a rapid growth in the UK's solar photovoltaic (PV) industry and crucially underwriting the financial viability of many CRE projects (Nolden, 2013b). However, since its introduction, the UK government has repeatedly backtracked on its support for FIT, significantly decreasing the level of payments both in 2012 (only for solar PV) and in 2016 (for all eligible technologies), and making access to the scheme more cumbersome (Martiskainen, 2014). In the Community Energy Strategy, FIT was envisaged as an easily scalable and low risk source of long-term income for CRE projects (DECC, 2014b) and most CRE business models depended on it. The reduction in this public subsidy has seriously undermined the financial viability of such renewable electricity projects, rendering it much more difficult for CRE organisations to expand, and virtually impossible for any new groups to enter the sector.

A wide range of quantitative and qualitative studies have investigated the reasons for the slow pace of development in CRE projects in the UK in comparison with other EU countries. In Germany, over half of the installed renewable energy generation is owned by local people (Seyfang et al. , 2013; DECC, 2014a; Haggett et al., 2014; A. L. Harnmeijer, 2016). According to Hall and Roelich (2015a) and Haggett et al. (2014), in addition to FIT, this success has been due the German government's consistent support for local subsidiarity, public benefit values and promotional lending while these factors are lacking in the UK energy sector. The volte-face by the UK government on FIT payments is symptomatic of the very different business culture that 
prevails in the UK energy industry. However limited data is available on the current scale of activity and the barriers that face CRE projects in the UK and how recent government policy has influenced their situation.

A number of researchers have also focused on the different elements that make up the business structure of CRE organisations. To name a few; Seyfang et al. (2013) and Walker et al. (2007) have conducted a broad survey of the key activities and geographical distribution of the sector, and the diverse organisational structure and ownership models has been examined by numerous researchers (Hielscher, 2011; Willis and Willis, 2012; Haggett, et al, 2014; Haggett and Aitken, 2015). However, this previous research has generally focussed on only a few elements of the business model canvas.

This paper explores four fundamental areas of the CRE business model structure, as identified by Osterwalder (2004): the value proposition, the customer interface, the infrastructure, and the revenue model. This way of mapping the different elements of a business model offers an in-depth understanding of the character of the UK's CRE sector and allows alternative business models to be readily compared and assessed. (Herbes et al, 2017). The purpose of this study is fourfold:

1. To gain an understanding of the impact of the curtailment of renewable support mechanisms in 2015 on the development of the UK's CRE sector.

2. To identify the challenges currently facing CRE organisations which aim to develop new projects.

3. To evaluate the various business models that CRE groups can potentially adopt under the new policy conditions, taking to account the available resources, financial risk-benefit and replicability.

4. To propose strategies which encourage the further growth of CRE groups.

This paper presents new empirical data obtained from an independent survey. A business model tool is used to provide an overview of CRE projects in the UK and to investigate the impact of the curtailment of renewable support mechanisms on their development. Alternative business models for the future development of the CRE sector are evaluated and some innovative approaches that organisations could adopt under the new policy regime are suggested.

Section 2 surveys the literature on business models relevant to CRE projects. The methodology used in the collection of empirical data for this study is described in Section 3. Section 4 then reports the results obtained 
and Section 5 makes recommendations and proposes alternative approaches based on a particularly promising business model.

\section{Theory}

\subsection{The business model concept}

Although the concept of the business model has become increasingly popular as an analytical tool among both practitioners and academics since the mid-1990's (Richter, 2013; Herbes et al., 2017), there is no universally accepted definition of the term. According to Richter (2011), for instance, a business model is a structural framework that defines a firm's organisational and financial foundation. Osterwalder (2004), on the other hand, defines it as the way an organisation creates and delivers value. There is general agreement, however, that a business model embraces four fundamental aspects: the value proposition, the customer interface, the infrastructure, and the revenue model (Osterwalder, 2004; Johnson and Suskewicz, 2009; Richter, 2011; Aslani and Mohaghar, 2013).

Community-owned projects, such as those aimed at promoting new energy technologies, have been identified in the literature as representing a specific type of business model (Huijbenn and Verbong, 2013; Asmus, 2008). Their 'bottom-up' approach and distinctive aims are often analysed using four main categories:

- Economic - revenue generation, economic growth and job creation (Hall and Roelich, 2016a)

- Social - fuel poverty reduction and social cohesion (Walker et al., 2007; Seyfang et al., 2013)

- Environmental - reducing the carbon footprint (Seyfang et al., 2013; Hall and Roelich, 2016b)

- Political - community empowerment, energy independence and local accountability (Seyfang et al., 2013; Hall and Roelich, 2016b)

CRE projects can be initiated in a number of ways: grassroots activism; partnership between communities and other organisations; or the commercial initiative of entrepreneurs and utilities. These different modes of development inevitably give rise to immense diversity in their organisational structure, ownership arrangements, financial resources, and legal frameworks (Hielscher, 2011).

The business model canvas proposed by Osterwalder (2004) has been used as an analytical tool by several researchers to classify renewable energy enterprises. For example, Aslani \& Mohaghar (2013) and Richter (2011) classify such businesses on the basis of the resources that they use (i.e. types of renewable energy technology) and the key activities in which they are engaged (e.g. generation, transmission or distribution). Although some have objected that the concept of the business model is only appropriate for profit-making firms, 
Ostwalder's definition, based on the way an organisation creates value for stakeholders, seems perfect applicable to non-profit companies, cooperatives and other social enterprises (Baden-Fuller and Morgan, 2010; Herbes et al., 2017).

\subsection{Defining CRE projects in a research context}

Existing literature categorises community energy projects in the UK under two types of communities: communities of locality and communities of interest (Bolinger, 2001; Stamford, 2004). 'Communities of locality' refers to people in particular geographical areas, while 'communities of interest' involve individuals living in different areas but sharing a common interest, for example, promoting the development of renewable energy (Bolinger, 2001). The definition of a CRE projects is often interpreted in different ways by policymakers, researchers, intermediaries and community participants, based on the degree of community involvement (Rogers et al., 2008; Hielscher, 2011).

The combination of the two words 'community' and 'renewables' in policy poses a fundamental question: what makes community energy projects different to other renewable energy projects? Walker and Devine-Wright (2008) answer this question by stating that CRE projects involve two dimensions of 'process' and 'outcome', a process dimension focusing on who projects are developed and run by, whereas an outcome dimension looking at how the results of projects are spatially and socially distributed; in other words, who gets what? (Walker and Devine-Wright, 2008). These twin criteria form the basis of the definition proposed by Seyfang et al. (2013), which is the one adopted in this study:

'A community energy project is one where communities (of place or interest) exhibit a high level of ownership and control, as well as benefiting collectively from outcomes'.

\section{Methodology}

A web-based survey of community energy groups was undertaken between August and October 2016. This involved compiling a list of relevant community energy groups and organisations in the UK from web-based searches. The membership lists of the following regional network organisations were used: Community Energy England, Community Energy Scotland, Community Energy Wales, Bristol Energy Network, Low Carbon Hub and Northern Ireland and Community Energy Co-Operative.

Around 430 community energy organisations were identified: 170 in England, 250 in Scotland and 10 in Northern Ireland. It was not possible to obtain contact details for all of these organisations and consequently, 
web-based questionnaires were only distributed to 364 of them.

Each group was approached at least twice to participate in the online survey. In total, 92 responses were received. After removing responses which provided insufficient data relevant to our study, the final total came to 72 organisations, representing a $20 \%$ response rate. As some of these were involved in more than one project or site, the total number of projects in the study was 502. This compares reasonably favourably with similar surveys carried out previously. For example, Seyfang et al. (2013) conducted a survey of 190 projects drawn from the whole CRE sector, focusing on their networking activities and project characteristics. A study conducted in June 2013 by the Department of Energy \& Climate Change to provide evidence for the Community Energy Strategy compiled 157 responses in its final sample (DECC, 2014a). Community Energy England also conducted a survey among its members in October 2015 to investigate the impact of FIT on CRE projects; it received 80 responses (Bridge and Fenna, 2015).

The questionnaires designed for our study used both closed and open-ended questions to gather information on the business model structure of the sampled groups. Descriptive analysis of close-ended questions was conducted and all responses to open-ended questions were analysed and coded using data analysis techniques.

Seven semi-structured interviews with boards of directors and CEOs were also conducted between November 2016 and June 2017 to validate the data collected from the online questionnaires. These interviews were either over the phone or face to face. Interviewees were selected from survey respondents who had agreed to participate in this way. The size of their organisations and the status of their projects was also taken into consideration. For instance, one of the interviewees, Chase Community-owned Solar, has 314 communityowned solar projects. All interviews were transcribed and analysed via descriptive coding in NVIVO.

\section{Results and discussion}

This section presents the results from the survey and interviews carried out for this study. A business model framework is used to characterise existing community energy organisations and describe the challenges that they have encountered since major policy changes occurred in the UK in 2015. 


\subsection{The morphology of the CRE groups in this study}

\subsubsection{Organisational structure of groups in the study}

The survey respondents came from a wide range of groups involved in CRE activities, including community energy organisations $(60 \%)$, voluntary/informal associations (15\%), intermediaries of community energy organisations (5\%), networks of local energy organisations and local authorities involved in community energy organisations (1\%). About $14 \%$ of the groups sampled did not provide sufficient information to classify their organisational structure. The majority of the groups were originated from civic and local actors and community energy was their main business activity $(72 \%)$.

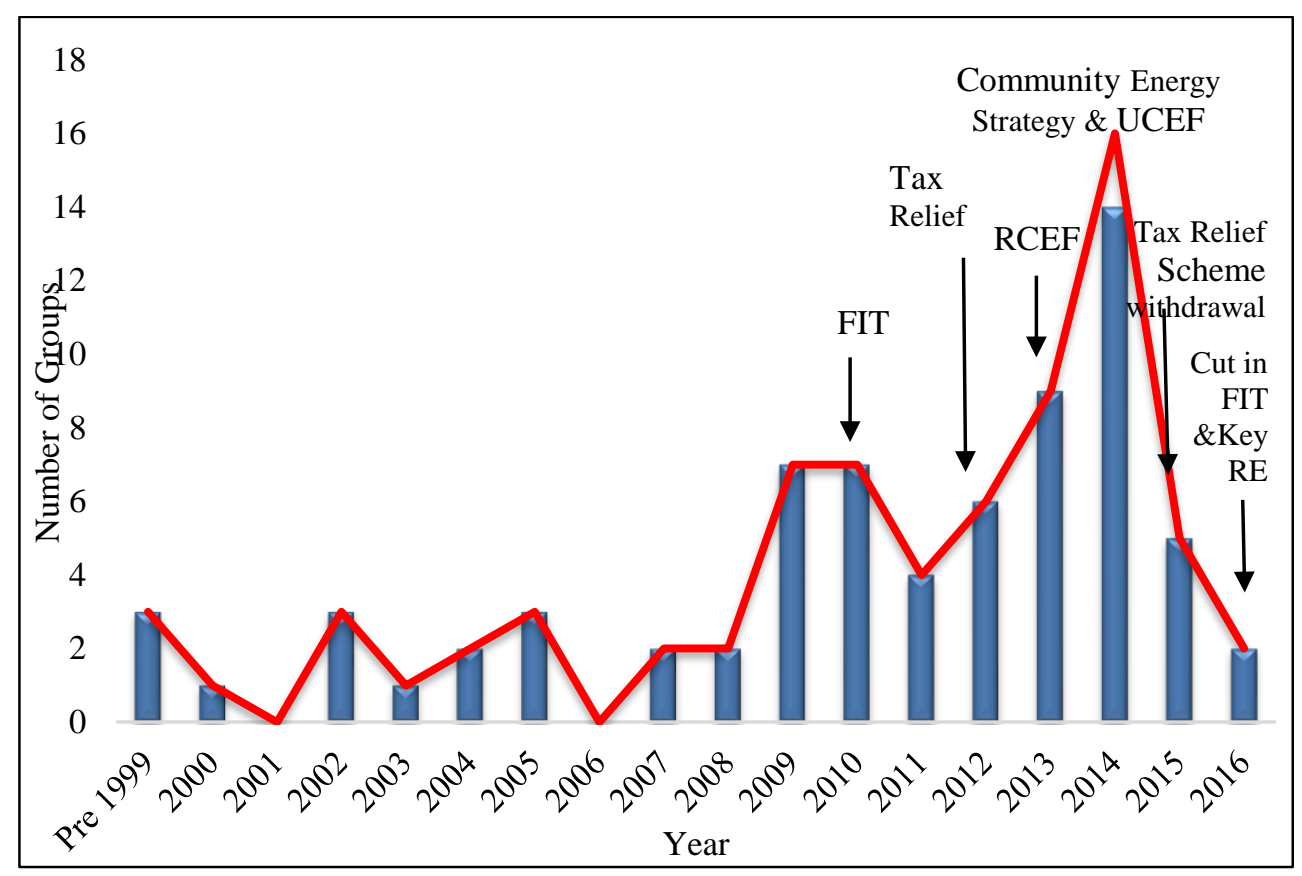

Figure 1: Community energy growth over a time

As shown in Figure 1, the community energy sector grew significantly between 2011 and 2015, but then declined rapidly in 2016. More than half of the respondents' projects (57\%) were established between 2011 and 2016. Worthy of special note is the fact that $20 \%$ of all the groups sampled were established in 2014 in direct response to the introduction of the Urban Community Energy Fund (UCEF) and the Community Energy Strategy in that year.

Figure 2 shows the geographical distribution of the survey respondents: South East England (22\%), Scotland (14\%), Wales (14\%), and South West England (13\%). 


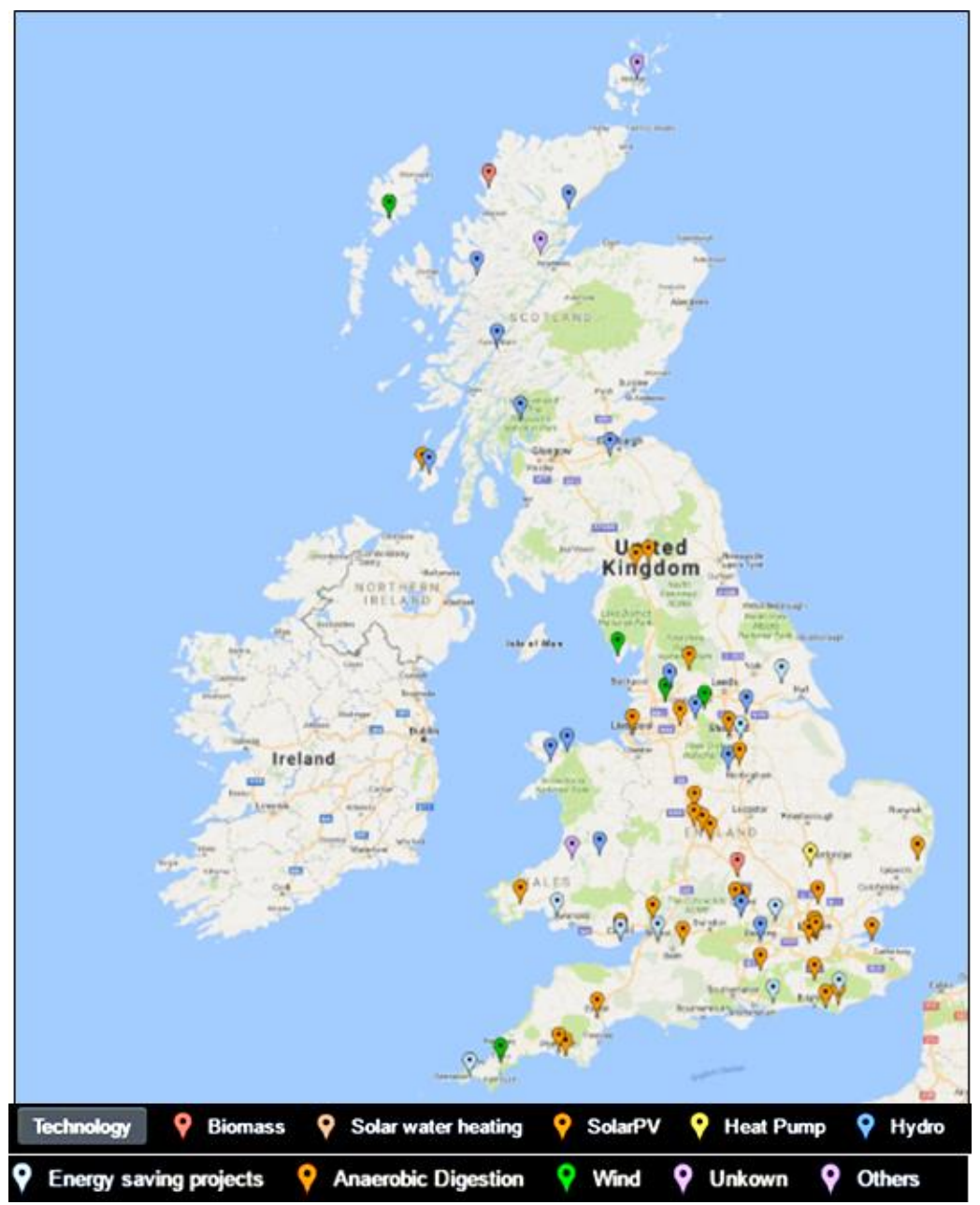

Figure 2: Geographical location of community energy projects in the study (complied by Author)

\subsubsection{Legal structures}

The survey showed that the UK's CRE market segment is regionally diverse in terms of legal structure (see Figure 3). $28 \%$ of respondents, mostly located in South East England, adopted the Community Benefit Society (CBS) as their legal structure. The Industrial Provident Society (IPS) was the legal structure of $22 \%$ of respondents and was most prominent in Scotland and North-West England. In addition to CBS and IPS-based organisations, cooperatives were also common in South East England, whereas in Wales, community interest companies limited by guarantee were favored. 


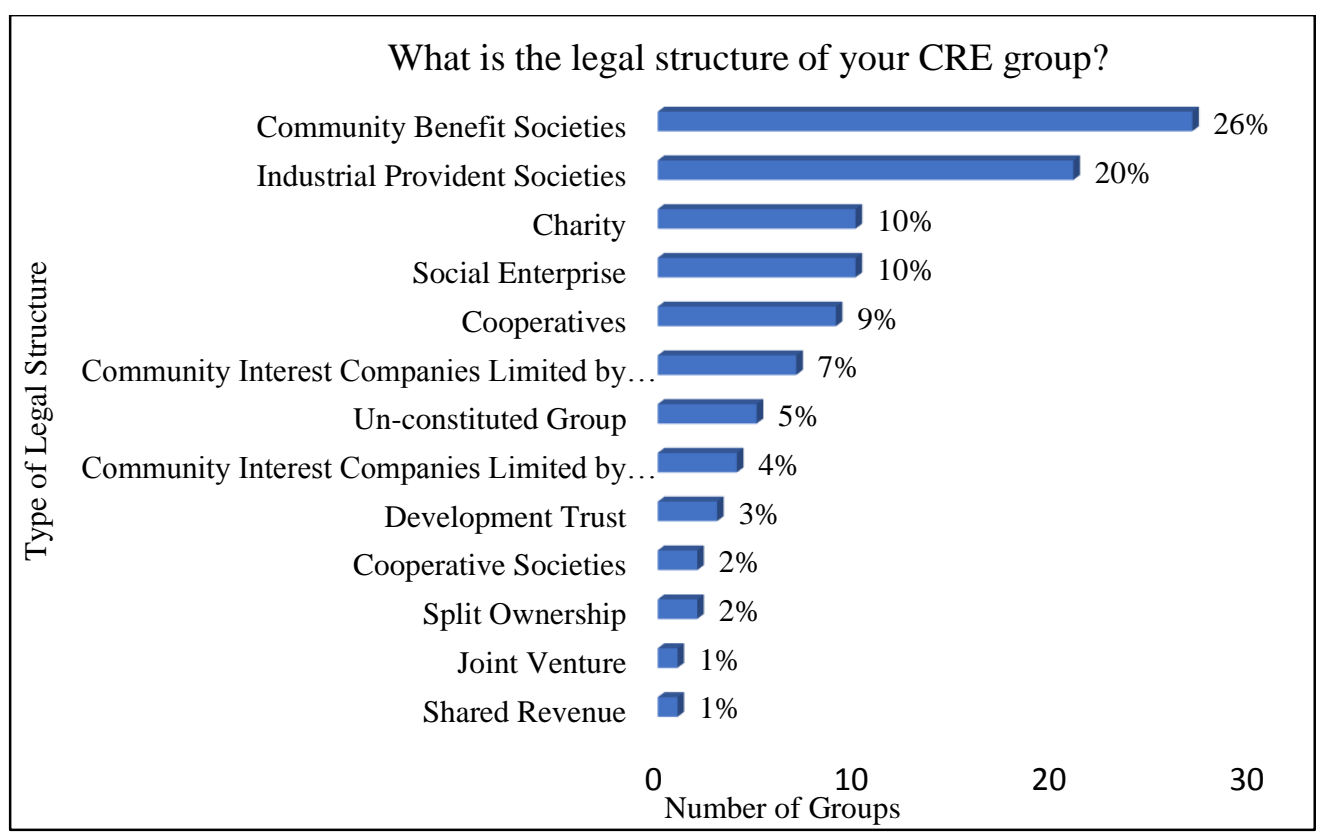

Figure 3: Legal structures groups in the study

\subsubsection{The most common business model among UK CRE groups}

This study uses the business model canvas of Osterwalder (2004 and 2005). CRE organisations can be classified into three groups: (a) the community finance model, (b) the community partnership model, and (c) the nonenergy-focused organisation (see Table 1). These categories have been structured mainly based on different type of ownership and key partners, the number of employees (key resources) and the different types of finance models. 
Table 1: The most common business models among UK CRE groups (adapted from Osterwalder, 2004

\begin{tabular}{|c|c|c|c|c|}
\hline $\begin{array}{l}\text { Business Model } \\
\text { Element }\end{array}$ & $\begin{array}{l}\text { Business Model Sub- } \\
\text { Element }\end{array}$ & Community Financed & $\begin{array}{l}\text { Community } \\
\text { Partnership Model }\end{array}$ & $\begin{array}{l}\text { Non-Energy Focused } \\
\text { Organisation }\end{array}$ \\
\hline \multirow[t]{2}{*}{ Value proposition } & ---- & $\begin{array}{l}\text {-Green Electricity/Heat } \\
\text { from local sources } \\
\text { - Local ownership and } \\
\text { decision making } \\
\text {-- Low risk financial } \\
\text { investment offering } \\
\text { competitive rate of return }\end{array}$ & $\begin{array}{l}\text { - Local ownership and } \\
\text { decision making } \\
\text { - Strengthening local } \\
\text { support for RE } \\
\text { development } \\
\text { - Engaging local people } \\
\text { with the concept of RE }\end{array}$ & $\begin{array}{l}\text { - Green Electricity/Heat } \\
\text { from local sources } \\
\text { - Reducing their bill } \\
\text { using renewable } \\
\text { electricity or heat on site }\end{array}$ \\
\hline & Customer segment & $\begin{array}{l}\text { - Owner of the premises } \\
\text { which the RE facility is } \\
\text { installed } \\
\text { - Consumer in general }\end{array}$ & Consumer in general & $\begin{array}{l}\text {-Owner of the premises } \\
\text { which the RE facility is } \\
\text { installed }\end{array}$ \\
\hline \multirow{3}{*}{ Customer interface } & Customer relationship & $\begin{array}{l}\text { - Simple energy provider } \\
\text { relationship }\end{array}$ & $\begin{array}{l}\text { - Simple energy } \\
\text { provider relationship }\end{array}$ & \\
\hline & Channels & $\begin{array}{l}\text { - Word of mouth } \\
\text { communication } \\
\text { - Social media/network } \\
\text { - Community energy } \\
\text { network organisations }\end{array}$ & $\begin{array}{l}\text {-Through online } \\
\text { investment platform } \\
\text { (Ethex, Abundance } \\
\text { Energy) } \\
\text { - Social media/network }\end{array}$ & $\begin{array}{l}\text {-Word of mouth } \\
\text { communication } \\
\text { - Social media/network }\end{array}$ \\
\hline & Key Activities & $\begin{array}{l}\text { - Multi-faceted (RE } \\
\text { generation } \\
\text { and Fuel poverty } \\
\text { alleviation) } \\
\text { - Financing distributed } \\
\text { Solar PV for community } \\
\text { buildings (Third party } \\
\text { premises), partly with } \\
\text { selling the electricity to } \\
\text { the premises owner }\end{array}$ & RE generation & RE generation \\
\hline \multirow{3}{*}{ Infrastructure } & Key Resources & $\begin{array}{l}\text { - Renewable installation } \\
\text { including Solar PV, } \\
\text { hydro, wind } \\
\text { - Expert volunteers/Paid } \\
\text { management } \\
\text { - Regional network } \\
\text {-Trust relationship with } \\
\text { prospective host owner }\end{array}$ & $\begin{array}{l}\text {-Renewable installation } \\
\text { including Solar PV, } \\
\text { hydro, wind } \\
\text { - Regional network } \\
\text { - Professionals /Paid } \\
\text { employees } \\
\text { Trust relationship with } \\
\text { community and } \\
\text { commercial developer }\end{array}$ & $\begin{array}{l}\text { - Renewable installation } \\
\text { including Solar PV and } \\
\text { renewable heat (e.g. Bio } \\
\text { mass) } \\
\text { - Expert volunteers }\end{array}$ \\
\hline & Key partner & $\begin{array}{l}\text { - Local Authorities (LA) } \\
\text { - Councils } \\
\text { - Host owners (schools, } \\
\text { community center) }\end{array}$ & $\begin{array}{l}\text { - Commercial RE } \\
\text { developer } \\
\text { - Intermediaries }\end{array}$ & $\begin{array}{l}\text { - Local Authorities (LA) } \\
\text { - Councils }\end{array}$ \\
\hline & $\begin{array}{l}\text { Up front finance } \\
\text { model }\end{array}$ & $\begin{array}{l}\text { - Government funding } \\
\text { schemes, } \\
\text { - Social private loans } \\
\text { - Local Authority (LA) } \\
\text { funding scheme } \\
\text { - Co-operative } \\
\text { investment, crowd } \\
\text { sourced debenture }\end{array}$ & $\begin{array}{l}\text {-Bank loans } \\
\text {-Commercial and social } \\
\text { private loans } \\
\text {-Cooperative } \\
\text { investment, crowd } \\
\text { sourced debenture }\end{array}$ & $\begin{array}{l}\text { - National lottery } \\
\text { - Gift/ Charitable funding } \\
\text { - EU funding scheme } \\
\text { - Government funding } \\
\text { schemes, } \\
\text { - Local Authority funding } \\
\text { scheme } \\
\text { - Sponsorship }\end{array}$ \\
\hline Financial model & Revenue & $\begin{array}{l}\text {-Public Subsidies } \\
\text { (FIT,RHI) } \\
\text {-Mixture of FIT/RHI \& } \\
\text { PPA }\end{array}$ & $\begin{array}{l}\text {-Public Subsidies } \\
\text { (FIT,RHI, and } \\
\text { renewable obligation) } \\
\text {-Mixture of FIT/RHI \& } \\
\text { PPA }\end{array}$ & $\begin{array}{l}\text { - Public Subsidies } \\
\text { (FIT,RHI) } \\
\text { Saving on the bills }\end{array}$ \\
\hline
\end{tabular}




\section{(a) The community finance business model}

Most organisations that took part in our study used this model. It describes projects which are developed, owned and run by members of a local community and function almost entirely with the help of volunteers. This model is not only associated with high cost-efficiency (Huijben and Verbong, 2013), but also encourages the involvement of local people in renewable energy investment and strengthens local support for new energy infrastructure. Community finance business models can be deployed in different forms to fund different types of renewable energy technology. It is commonly adopted by small-scale solar PV projects for community buildings, for instance. Typically, an organisation leases space for its energy-producing activities from a community building such as a school or social housing blocks, while retaining ownership of the technology and revenue streams. This model enables energy to be offered at a much lower price than that from the National Grid. A recent study found that in total $£ 172,500$ was saved annually by 20 different energy schemes of this kind across the UK (Bridge and Fenna, 2015). Under this business model, CRE organisations can also work in partnership with local authorities and councils in order to install their facilities on sites owned by the community. Upfront costs for these projects are financed by community shares and crowd-sourced debenture. Additional capital investment can also sometimes be provided by grants.

\section{(b) The community partnership model}

A few of the CRE projects sampled involved a partnership between a renewable energy developer and a CRE organisation. Commercial developers are often willing to get involved in these projects because wish to strengthen local support for their enterprises and disarm 'Not in My Back Yard' (NIMBY) resistance (DECC, 2014b). Such projects are financed by community shares and crowd-sourced debenture, with additional funds coming from banks and commercial loans. They are usually run by commercial developers employing professional staff, so local communities are less directly involved.

Community partnership, also known as shared ownership, can be implemented by using one of the following models: joint venture (JV), split ownership, or shared revenue (Haggett et al., 2014). In this study, two groups with split ownership were identified, one group with a shared revenue arrangement, and one group with a JV structure. In the split ownership model, a project is divided between two or more separate generation plants, one of which is owned and run by the community and the other by the commercial developers.

\section{(c) Non-energy-focused organisation}

This type of model consists of an existing community organisation, like a school, church or club, which works on renewable energy projects as an adjunct to its main activities. Such groups usually function as a charities or trusts, and their main aim is to increase social responsibility and save money by using renewable energy on site. 
The community is involved as a result of individuals being either members or beneficiaries of the parent organisation. The upfront costs are often funded by charitable donations or by grants.

\subsubsection{Key activities}

This study reveals the multi-faceted nature of community energy projects (see Figure 4). Among our survey respondents, $33 \%$ were solely focused on energy generation and $20 \%$ on energy saving projects. Almost half $(47 \%)$, however, engaged in diverse activities, including energy efficiency, energy generation and providing consultancy to other community energy projects.

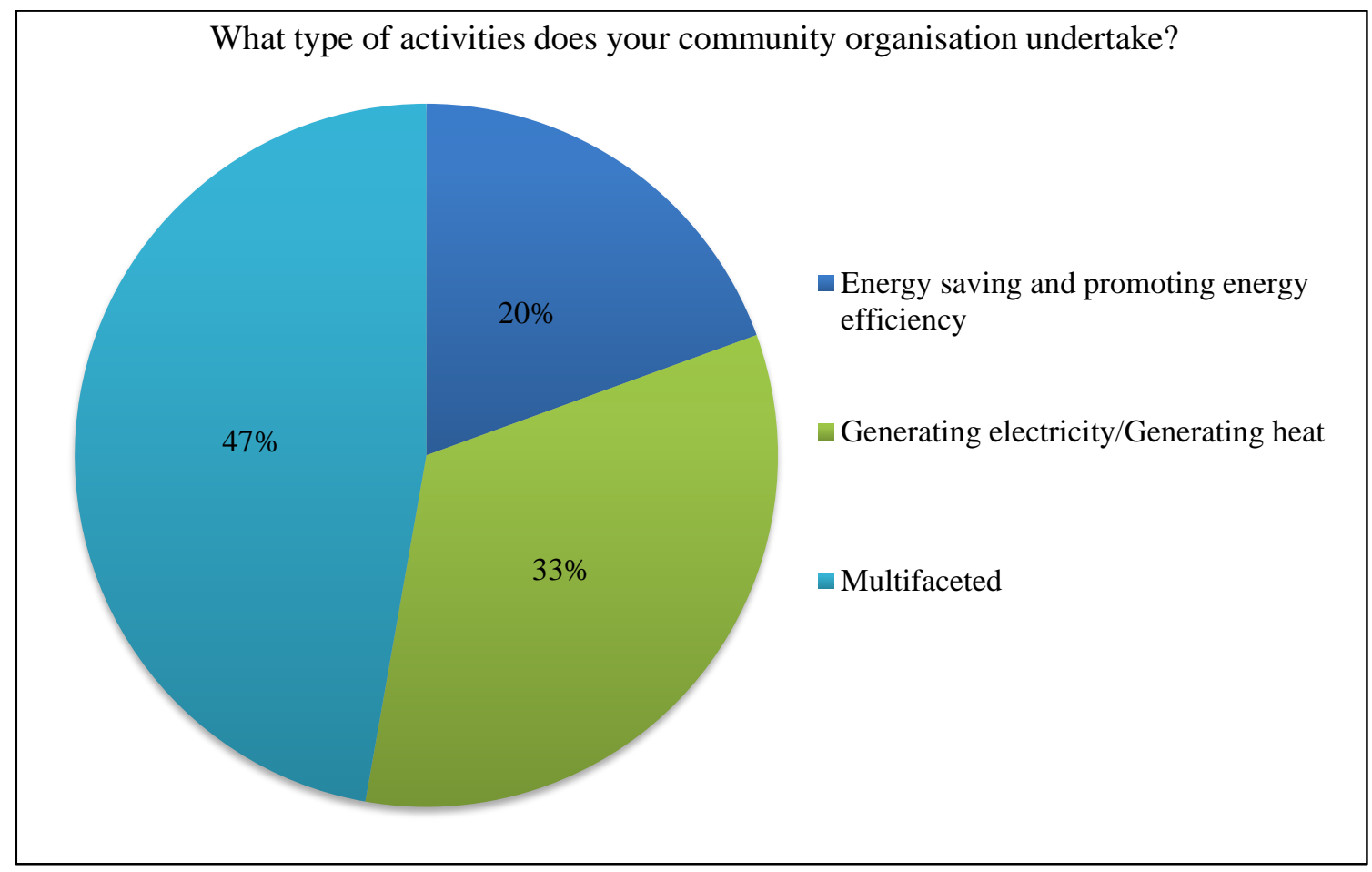

Figure 4: The UK’s community energy group activities (pre-2016)

\subsubsection{Key resources}

Solar PV was by far the most commonly used renewable technology (50\%), with the vast majority of these projects being at the operational stage (see Figure 5). Hydro was the next most common technology (22\%), followed by onshore wind (11\%). Due to geographical factors, hydro was most common in Scotland and Wales, whereas solar PV was dominant in England. A few groups in the study were not active, including five hydro schemes, three solar PV schemes and one Anaerobic Digestion (AD) scheme. The main reason given for these 
failures was the dramatic reduction in FIT and the removal of pre-accreditation, which had undermined the projects' financial viability.

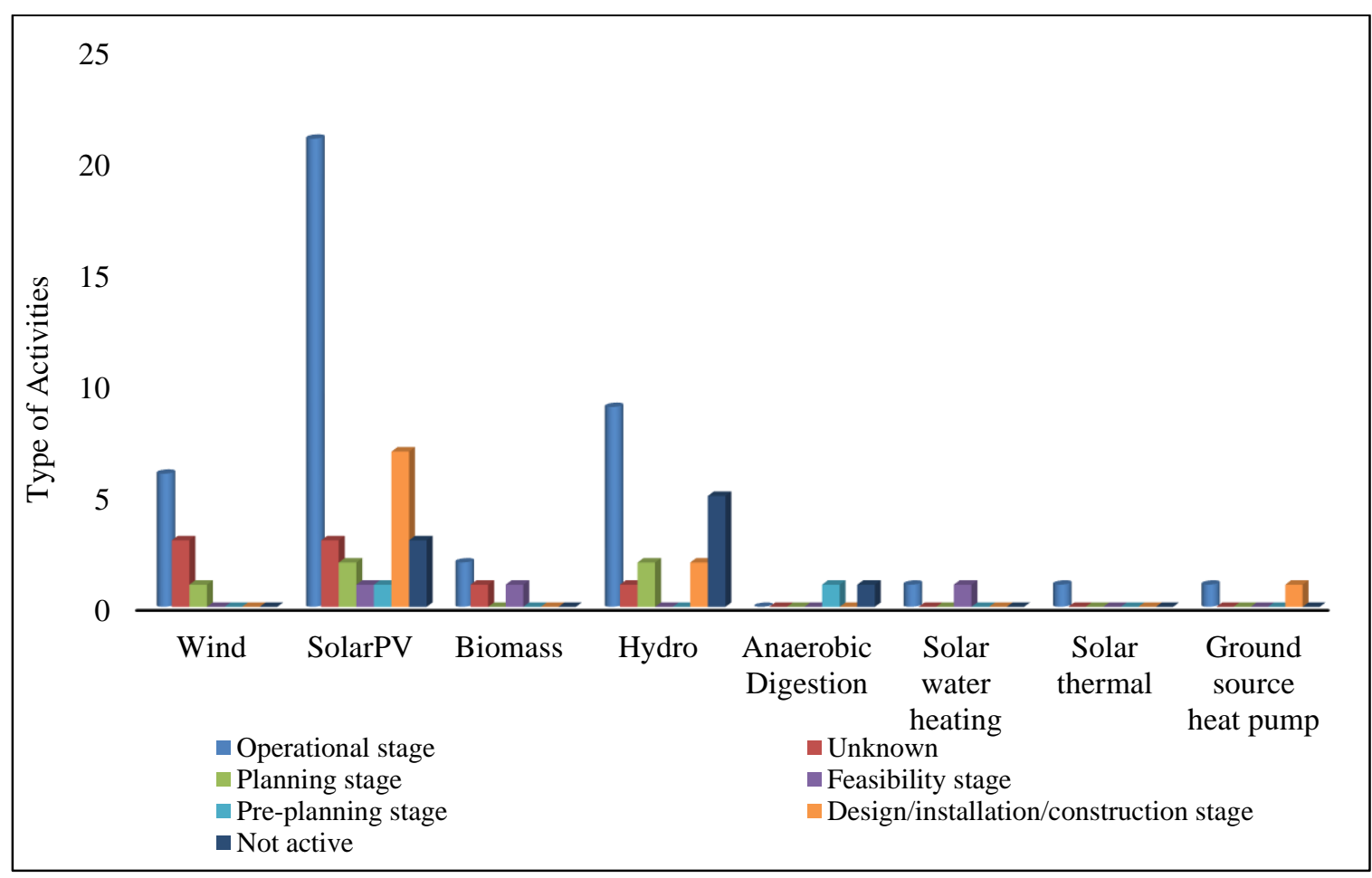

Figure 5: The different types of technology developed by UK CRE projects, and their different phases of project development

The majority (68\%) of the responding CRE organisations did not have any paid employees, relying instead on the skills of volunteers during the setting up and development stages of their projects (see Figure 6). 


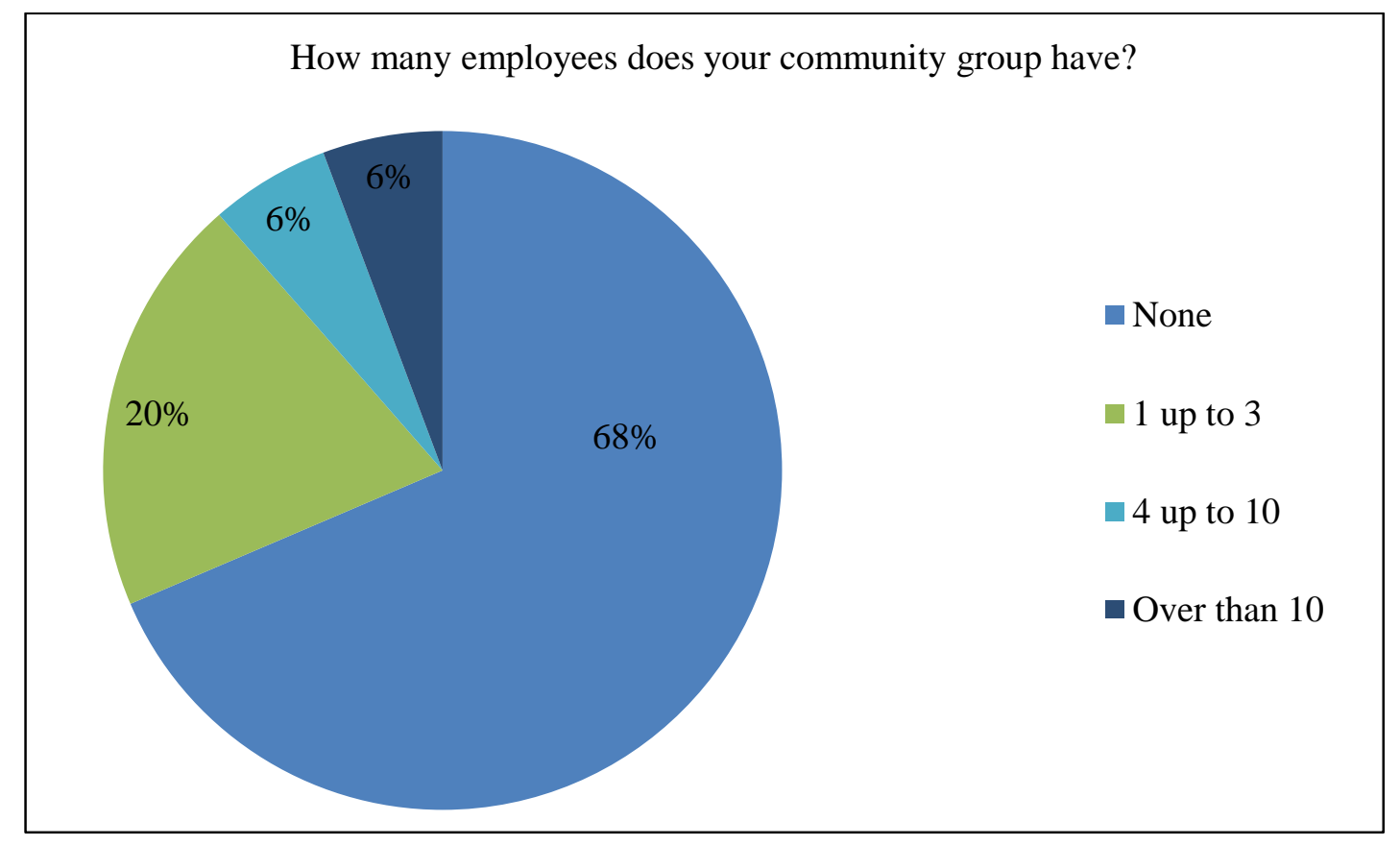

Figure 6: Number of employees of UK's community energy group/ organisation

\subsubsection{Revenue and Financial model}

Historically, CRE projects have been extensively dependent on grant funding. Although not always awarded, grants were widely regarded as a sound way to develop renewable energy projects (Nolden, 2013a; C, 2014a).

Following the introduction of FIT and RHI in 2010, confidence in the financial security of CRE increased and alternative ways to raise capital for such projects began to materialise (Catney et al., 2013; Nolden, 2013a). However, the CRE sector was still heavily dependent upon public subsidy. As shown in Figure 7, 29\% of community energy groups used grant funding to finance their projects whilst $20 \%$ used non-grant funding, such as community share and loans. As Walker (2008) has observed, community-led energy projects often use multiple sources to finance their projects. 


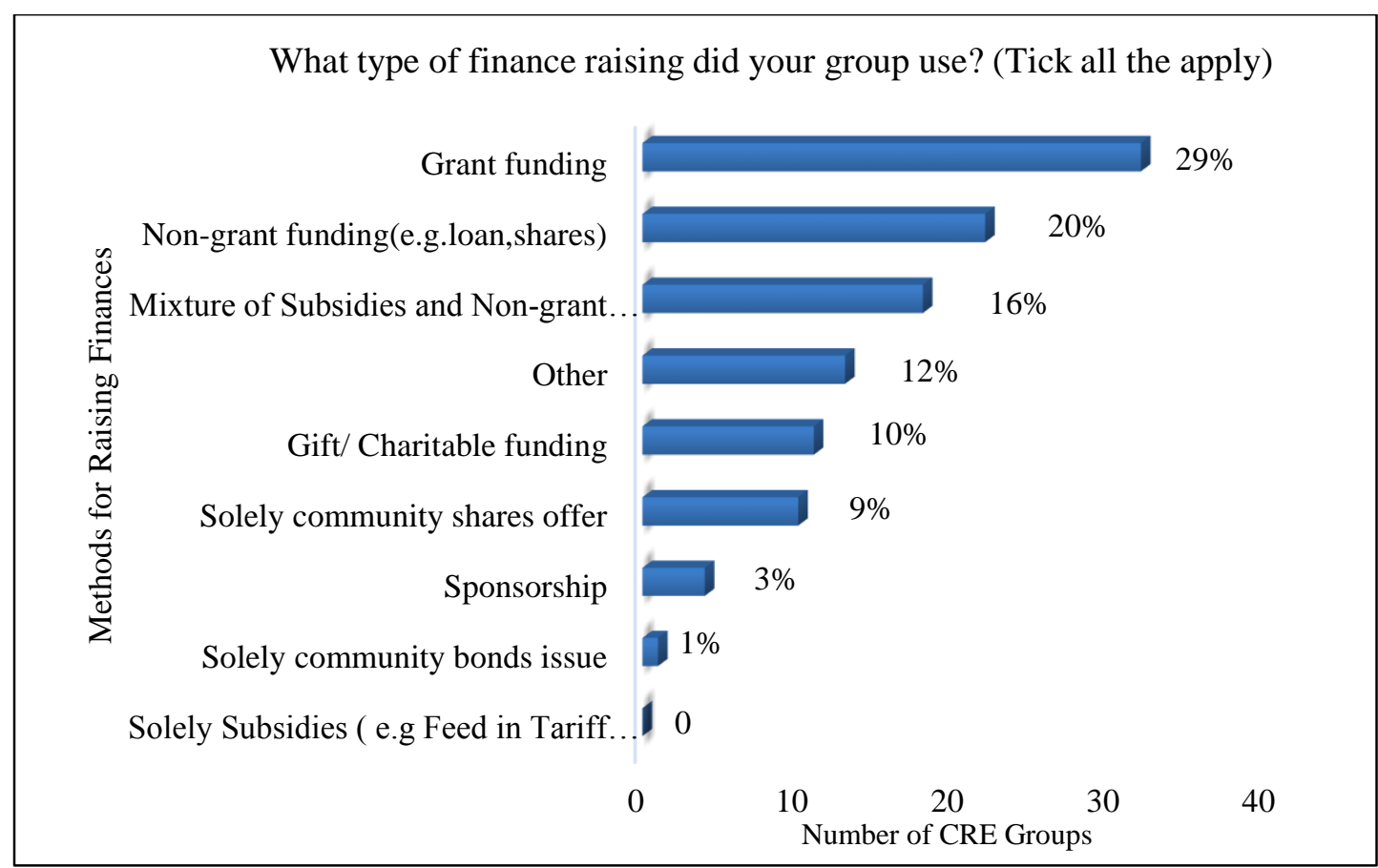

Figure 7: UK CRE organisations methods for raising finances $(n=72)$

In this study, over half of the groups who used grant funding (54\%) also used other sources, with some using up to 5 different sources. Only $9 \%$ solely used a community share offer to finance their projects. The majority of groups (43\%) used a government funding scheme (see Figure 8). Social or private loans were used by $17 \%$, and $16 \%$ used a local authority funding scheme. 


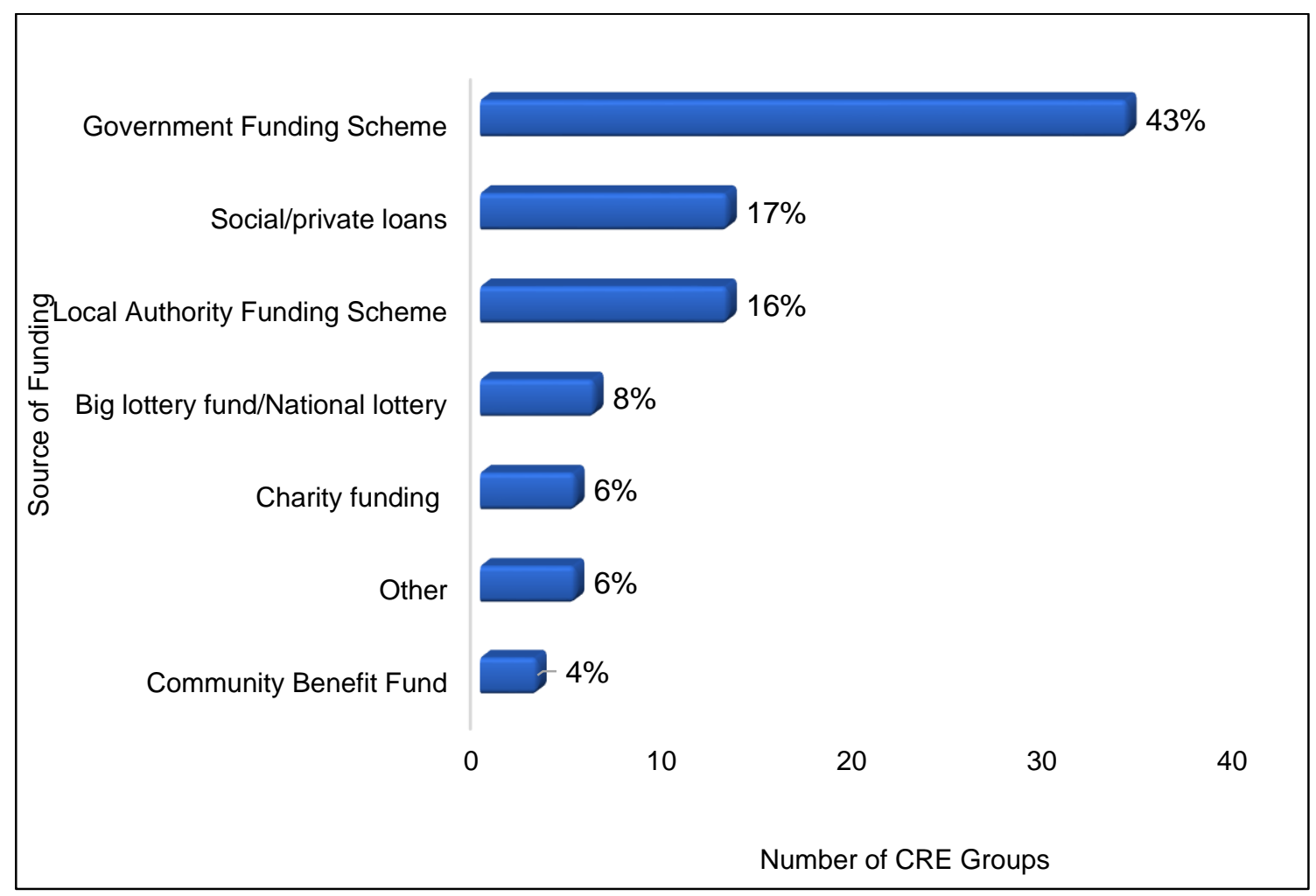

Figure 8: UK's CRE organisations source of funding $(n=72)$

This study shows that the income of the majority of organisations (75\%) primarily comes from public subsidies. One of the critical challenges facing CRE projects following the FIT reduction in 2016, therefore, is to maintain a consistent stream of income which is less dependent on such subsidies and generated instead by selling electricity or heat independently. A quarter of the groups studied had no other source of income. A similar number did not have any income at all, either because they were in the process of being set up or had become inactive. 


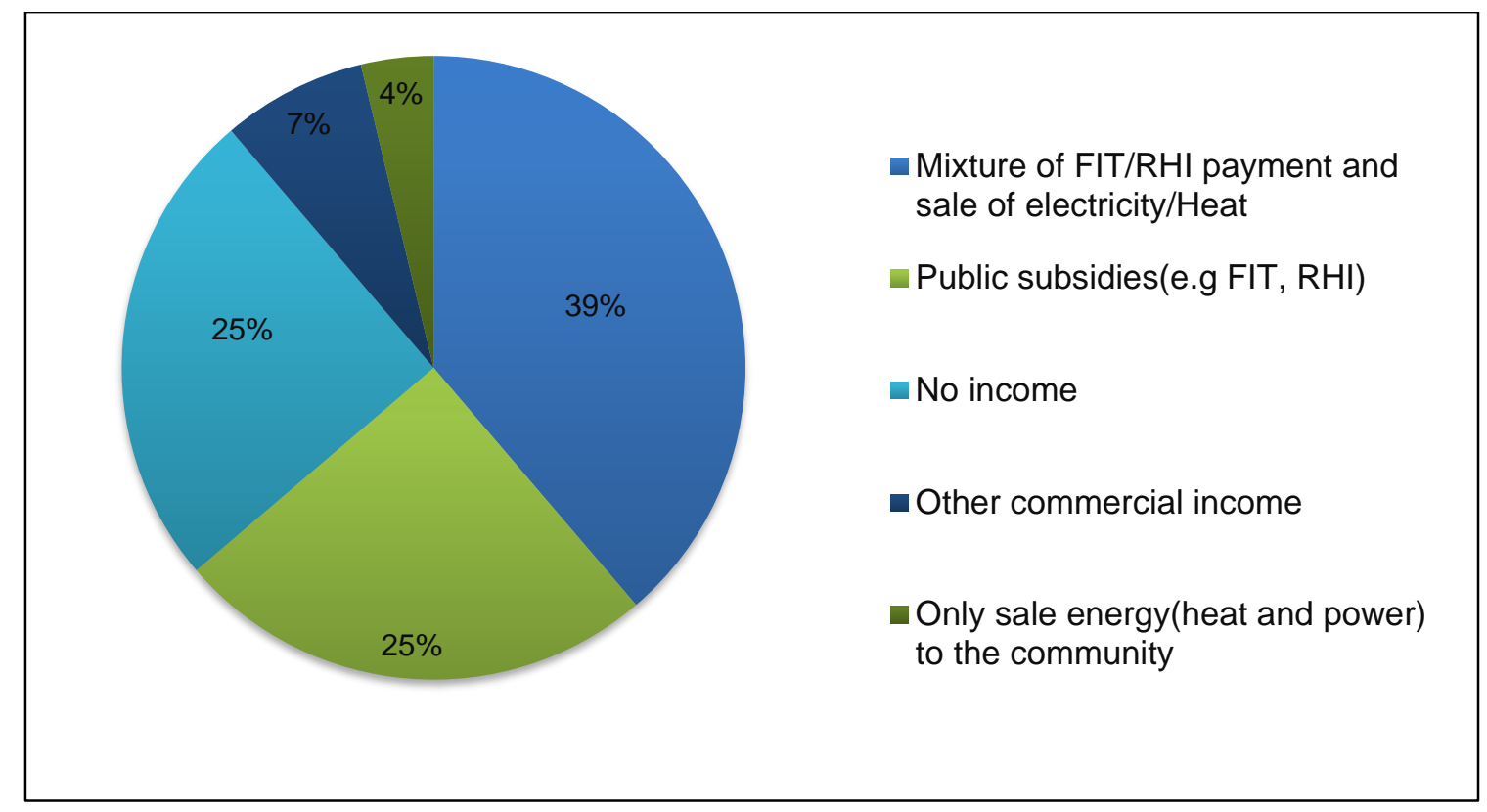

Figure 9: UK's CRE organisations source of revenue $(n=72)$

The largest group of respondents (39\%) of respondents, however, relied on a mixture of subsidies (FIT and RHI) and the direct sale of electricity to site-owners or host organisations through a Power Purchase Agreement (PPA). These were groups that had adopted a community finance business model, often leasing space (or a roof) to install and operate solar PV technology and then selling the electricity generated to the lessor under the terms of the PPA at a much lower price than the market rate (typically 5-7 pence per $\mathrm{kWh}$ ). Depending on the amount of energy consumed locally, they also receive FIT payment for generation and export.

\subsection{The impact of post-2015 policy changes on community energy activities}

According to Hielscher et al. (2010), uncertainty surrounding the amount of support that the government should provide can be detrimental for community-led groups. As Figure 10 indicates, 69\% of groups in the study reported that the FIT reduction had adversely affected their projects' development. $15 \%$ of the respondents confirmed that their projects were affected by the removal of the FIT pre-accreditation which was introduced alongside the FIT reduction in 2011 and 2012, and was ended on 8th February 2016 for community groups 
(Nolden, 2015). FIT pre-accreditation meant that renewable energy projects which generated over $50 \mathrm{~kW}$ of energy and which had secured planning consent and grid connection were able to receive a guaranteed FIT level before the projects started (ofgem.gov.uk, 2016). Community groups which produced less than $50 \mathrm{~kW}$ of energy through solar PV could access pre-registration. Taken together, FIT pre-accreditation and pre-registration gave organisations certainty about the price that they would receive for the electricity they generated prior to the project installation phase. Removing these two provisions meant that any project planned after 2015 would only be entitled to receive the rate of subsidy current at the date of its completion.

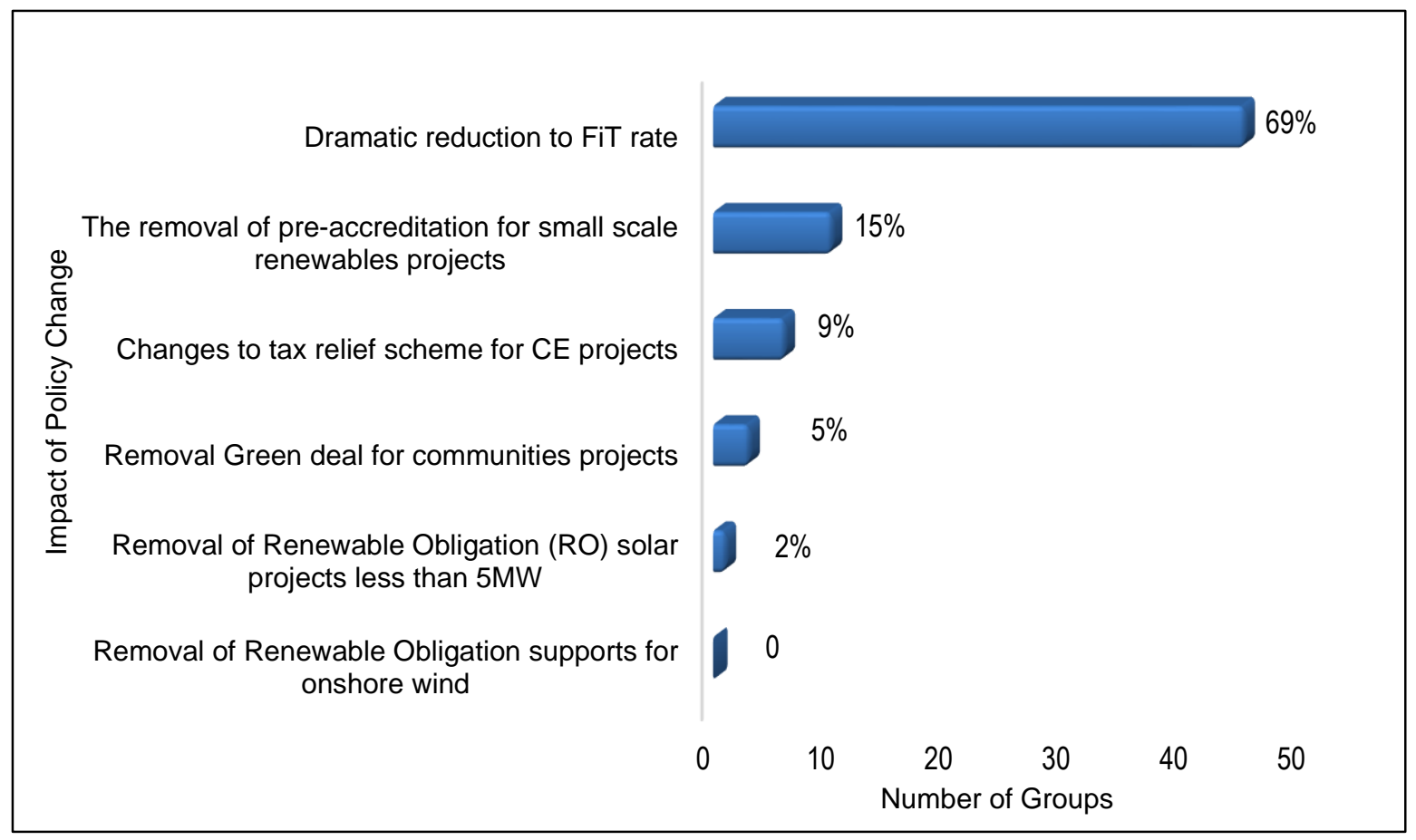

Figure 10: The impact of policy changes on CRE activities

\subsubsection{Reasons given for the failure of CRE projects following policy changes}

Community energy projects are not widely diffused in the UK, and are therefore very vulnerable to changes in government (Nolden, 2013b; Seyfang et al., 2013). Recent policy uncertainty has made it difficult for projects to be run successfully and virtually impossible for any new groups to enter the sector. This study's survey findings strongly support the observations of Hielscher et. al (2010), namely that community-led 'grassroots' innovation tends to remain relatively small-scale and fails to develop due to a lack of institutional and long- 
term financial support.

Of the 502 schemes run by the respondent CRE organisations, 89 never progressed beyond the planning or feasibility-study stage. $10 \%$ of these organisations were at the stage of developing their first renewable energy schemes, but they failed due to policy uncertainty and have since become inactive.

The following reasons were cited for this failure to continue with their enterprise:

A hydro scheme located in the South of England and established in 2010, reported:

"We had pre-accreditation, but that set a time limit which made construction more expensive. Our project got as far as tenders, but the price turned out to be much higher than the QS estimate so the project was not viable. Shares have now been bought back and the Society is being dissolved." (6)

A small-scale hydro scheme established in 2009 in England stated:

"Our small-scale hydro scheme on the river [xxxx] had reached the stage of submitting a planning application, but was rendered no longer viable by the reduction in FIT rate and changes to the tax relief scheme." (4)

Another in-active scheme located in Wales stated that:

"Our grant funding was cancelled in advance research feasibility phase due to FIT reduction although our project was feasible." (3)

These statements indicate that small-scale hydro schemes which were newly set up prior to the FIT reduction and pre-accreditation removal were unsuccessful in completing their project installations due to time limits and cost. The FIT generation payment for hydro schemes generating less than $500 \mathrm{~kW}$ energy was reduced dramatically by periodic degression, causing widespread financial difficulties. The British Hydropower Association (BHA) supports this conclusion; their figures show that many new applications for water extraction failed during the period 2014 - 2015 due to FIT degression over time (Nolden, 2015). Furthermore, the voluntary nature of community energy organisations meant that they lacked the professional staff and expertise to handle such an uncertain institutional landscape.

A survey respondent located in Wales stated: 
"Although our $30 \mathrm{~kW}$ Anaerobic Digestion and $30 \mathrm{~kW}$ solar project were at feasibility stage the removal of government support made it much harder for a small group of enthusiastic local members to continue with the project."

A CRE project located in Cornwall, South West England that had three volunteers and no paid staff reported:

"Due to a lack of people in our group, we weren't able to develop the project fast enough before subsidies went."

Out of the 89 schemes that did not go ahead (Table 2), 20 provided installed capacity details for their potential projects. This amounted to approximately 18MW, including 14MW of solar PV energy across seven schemes, $400 \mathrm{~kW}$ of hydro energy across four schemes, $3.5 \mathrm{MW}$ of onshore wind energy across seven schemes and $350 \mathrm{~kW}$ of $\mathrm{AD}$ energy across two schemes.

This study shows that the FIT reduction and removal of FIT pre-registration were particularly disruptive to community solar projects. 71 respondents had failed to complete their schemes. The most common reasons given were: the loss of the economic viability caused by the reduction in FIT; missed FIT deadlines due to a lack of staff; and refusal of planning permission for large-scale projects. The main reasons reported for the failure of hydro projects were: the high level of financial risk caused by the removal of FIT pre-accreditation; the refusal of grid connection for $100 \mathrm{~kW}$ schemes; and missed FIT deadlines. The removal of FIT preaccreditation was a particular problem for hydro schemes because they typically take 2-5 years to be developed, and are therefore vulnerable to changes that affect their financial viability within that long set-up period. Table 2: Projects which failed due to post-2015 policy changes

\begin{tabular}{|c|c|c|}
\hline Name of Technology & Number Scheme & Cause of Projects Failure (based on survey respondents) \\
\hline Hydro & 8 & $\begin{array}{l}\text { - High risk with the lack of pre-accreditation } \\
\text { - Missed FIT pre-accreditation deadlines } \\
\text {-Grid connection constraint refused } \\
\text {-Time limit caused construction to be more expensive }\end{array}$ \\
\hline Solar & 71 & $\begin{array}{l}\text { - Missed FIT pre-accreditation deadline } \\
\text { - Lead partner refused to become an energy supplier, "largely on } \\
\text { the basis of the post-election ministerial statement" } \\
\text { - Made it unviable by FIT reduction } \\
\text { - Lack of resources - enough people to deliver the project }\end{array}$ \\
\hline Wind & 8 & $\begin{array}{l}\text { - Planning permission refused due to ministerial statement of } \\
\text { June } 2015\end{array}$ \\
\hline Anaerobic Digestion & 2 & - Substantial risk involved \\
\hline Grand Total & 89 & ----- \\
\hline
\end{tabular}




\subsubsection{Challenges facing CRE organisations that aim to develop new projects under new renewable} policy conditions

As shown in Table 3, this study reveals that a lack of sufficient knowledge about appropriate business models for projects is a key challenge facing $23 \%$ of community-based energy groups.

A second barrier to the successful establishment of CRE projects is a general lack of policy support. This was the greatest challenge facing the development of some groups, even before the curtailment of support mechanisms (Nolden, 2013a), but the change of policy in 2015 undoubtedly made the situation much more difficult. $15 \%$ of respondents reported that, following the change in policy, raising capital from members of the community had become more challenging because of a smaller return on investment and the unknown rate of FIT. Previously the FIT scheme delivered a reliable return of between $5 \%$ and $8 \%$ on investment in small-scale renewable energy. With the new reduced FIT, this fell to around $1 \%$. One respondent commented:

"We had originally planned to install roof-top solar PV on 20 sites, but 16 did not go ahead because of the removal of pre-registration and reduction in FIT. Both had a serious impact, but the pre-registration was arguably worse because it meant we had no way of knowing what the FIT rate would be when the sites were accredited, and this uncertainty would make it incredibly difficult to raise the required capital from members of the community." 
Table 3: The main challenges to CRE projects under new policy conditions based on the business model of Ostwalder (2004)

\begin{tabular}{|c|c|c|c|c|}
\hline $\begin{array}{c}\text { Elements of the business } \\
\text { model Canvas }\end{array}$ & Internal barriers & Percentage & External barriers & Percentage \\
\hline Key resources & $\begin{array}{l}\text { Lack of knowledge to } \\
\text { develop business model for } \\
\text { new projects (business } \\
\text { model innovation) }\end{array}$ & $23 \%$ & ------------------ & --------- \\
\hline $\begin{array}{l}\text { Financial model (upfront } \\
\text { cost) }\end{array}$ & $\begin{array}{l}\text { Difficulty in raising capital } \\
\text { through community share } \\
\text { due to the lack of } \\
\text { profitability }\end{array}$ & $15 \%$ & $\begin{array}{l}\text { - Finding funding due to } \\
\text { the policy changes (such } \\
\text { as withdrawal of the } \\
\text { UCEF) }\end{array}$ & $16 \%$ \\
\hline Revenue & $\begin{array}{l}\text { Lack of viable business } \\
\text { model and substantial risk }\end{array}$ & $15 \%$ & $\begin{array}{c}\text { - Lack of structured policy } \\
\text { supports }\end{array}$ & $18 \%$ \\
\hline \multirow[t]{2}{*}{ Other factors } & Community engagement & $5 \%$ & ---------------------- & \\
\hline & $\begin{array}{l}\text { Locating viable sites for new } \\
\text { projects }\end{array}$ & $8 \%$ & ------------------------ & \\
\hline
\end{tabular}

Another challenge mentioned by several groups in the study that were planning a distributed solar PV scheme was locating suitable sites for generating energy; there is very little financial incentive for site-owners now that FIT has been reduced. As one respondent explained:

"Economic viability is much harder with reduced FIT. PPA now needs to charge almost as much as grid, so financial incentives for site-owners are greatly reduced and it is even harder to obtain a roof-top lease and a PPA agreement. You also need to have a high proportion of on-site use for viability. The loss of preaccreditation causes forward-planning to be packed with uncertainty and risk. Tax relief removal was unhelpful, but not the main problem."

\subsection{Approaches taken by CRE organisations in the UK under the new policy conditions}

Figure 11 shows the strategic approaches that CRE groups in this study have undertaken or are planning to undertake in response to the recent changes in government policy. The effects of some of these can already be observed in the market. 


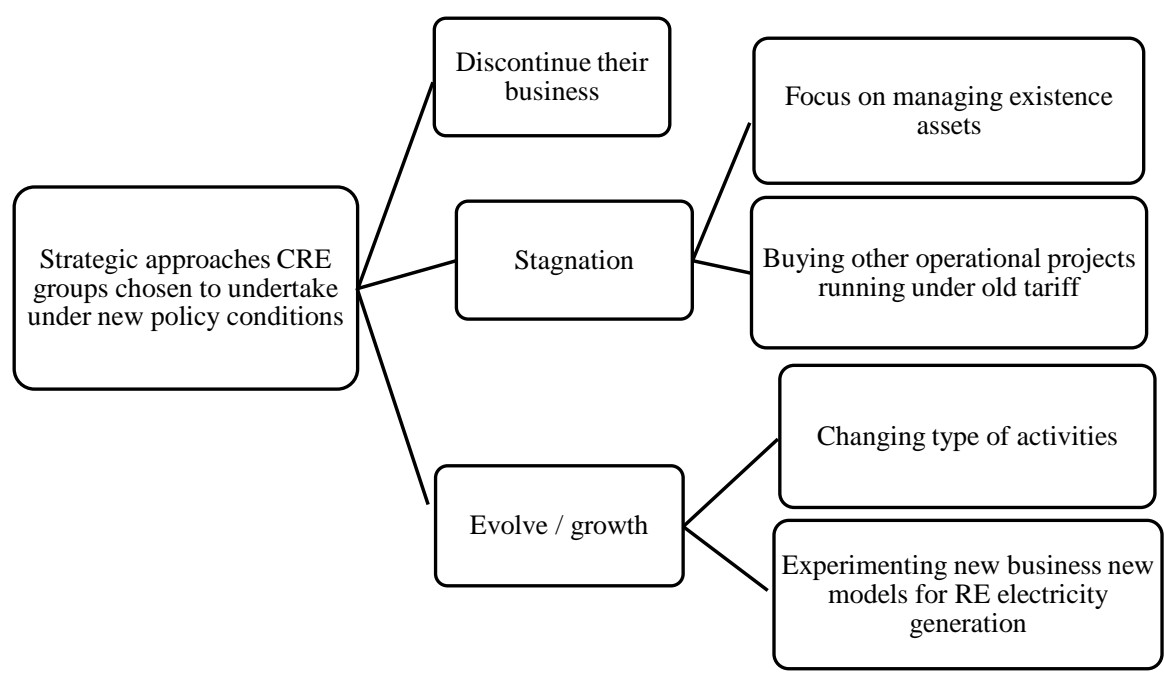

Figure 11: Strategic approach undertaken by UK CRE groups under new renewable policy conditions

It has been argued that such stagnation is a common feature of grassroots projects, which typically function at only a subsistence level because of the constant need to sustain the enthusiasm of volunteer supporters. (Seyfang and Smith, 2007). However, the policy changes in 2015 did nothing to ameliorate that tendency. As mentioned in Section 4.2.1, $10 \%$ of survey respondents had been forced to discontinue their businesses due to the policy changes. $61 \%$ of CRE groups who took part in the study had decided to focus on managing their existing assets, rather than develop further. The majority of groups had become inactive reported that their members had lost the motivation to develop further projects within the sector as a result of the institutional changes. One community representative commented:

"It is harder to raise community share capital for community energy schemes, and therefore we have stopped looking for new projects."

A respondent located in England stated:

"The changes removed our motivation to begin further projects."

Only $29 \%$ of respondents were planning to undertake new projects under the new renewable energy policy conditions. Among them, a minority reported that they were planning on the basis of the new FIT rate (12\% for 
PV and 6\% for wind). However, the majority of groups intended to change their key activity: $28 \%$ reported that their new projects would primarily focus on energy efficiency; $21 \%$ were aiming to experiment with a new business model (e.g. microgeneration with storage); and 15\% aimed to switch to renewable heat projects. Some groups stated that their projects would involve investment in more energy-efficient LED lighting in the future, which would enable them to reduce their costs and emissions. Interestingly, $15 \%$ of these groups planned to buy other operational RE projects running under an old FIT rate. This approach would not add to RE capacity in the energy system overall, but would just help the groups survive, so it should be considered as another form of stagnation.

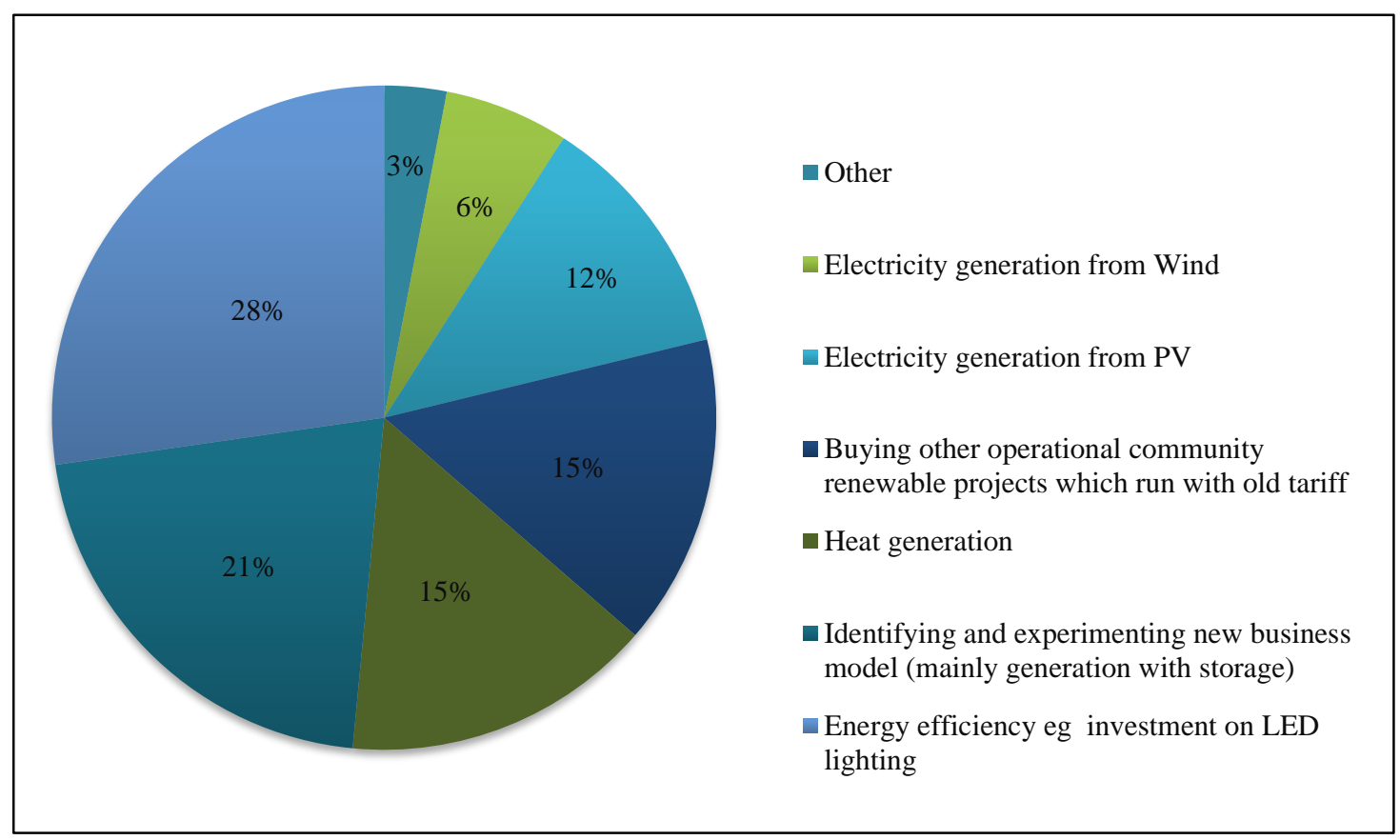

Figure 12: What type actives will/did you undertake under new policy regime $(n=28)$

\subsection{Business model innovation for the UK's CRE projects}

This section provides a brief overview of the problems facing CRE organisations looking to develop an innovative business model for further growth or to maintain an existing level of productivity, given the current regulation in the UK. 


\subsubsection{Challenges to business model innovation}

Business models can be crucial catalysts for the diffusion of new technologies, enabling organisations to reduce financial uncertainty and manage change (Strupeit and Palm, 2015). According to Bolton \& Hannon (2016), business model innovation can involve implementing new business activities, connecting activities in novel ways or changing the way that a certain party carries out an activity. Schneider \& Spieth (2013) defined 'business model innovation' as a fundamental modification in the way firms create and capture value to produce results which exceed those that would be created simply by incremental adjustment to an existing business model. Innovative technologies can act as a driver for business model innovation, but some models, such as car-sharing, do not necessarily require technological innovation (Bidmon and Knab, 2014).

Several internal and external barriers obstructing business model innovation have been identified in the literature. These fall into two categories: those directly related to the business model, including a lack of resources (e.g. time, finance, expertise) (Richter, 2013; Hall and Roelich, 2016; Herbes et al, 2017), a lack of policy support (Aslani and Mohaghar, 2013), and a lack of profitability ( Herbes et al., 2017); and those which are unrelated to the business model caused by things like a lack of public awareness and social acceptance.

\subsubsection{Opportunities and challenges for CRE projects under the new renewable policy regime}

Participants of this study were asked to comment on possible approaches to innovation that CRE projects could adopt under the new renewable policy conditions.

As shown in Table 4, over a quarter of respondents suggested that direct supply business models, which enable organisations to sell electricity directly to local communities or third-parties, might enable CRE schemes to remain viable under the new regime. For the majority of the UK's CRE groups, the only current way to enter the market for locally generated energy is through a PPA with a third-party licensed supplier (TPLS) or trader (Hall and Roelich, 2016). The terms of such PPAs have become much less advantageous in recent years, so it is highly likely that local generators would receive a lower price for their energy that was not economically viable under current UK legislation (Hall and Roelich, 2015). 


\begin{tabular}{|c|c|c|c|c|}
\hline & $\begin{array}{l}\text { Local } \\
\text { Supply } \\
\text { Model }\end{array}$ & $\begin{array}{l}\% \text { Suggested } \\
\text { by Community } \\
\text { Representatives }\end{array}$ & Replicable for & Barriers \\
\hline \multirow{3}{*}{$\begin{array}{l}\text { Partnership } \\
\text { with } \\
\text { supplier }\end{array}$} & $\begin{array}{l}\text { Direct } \\
\text { Supply }\end{array}$ & $28 \%$ & Conventional CRE projects & $\begin{array}{l}\text {-Lack of profitability } \\
\text {-Lack of clear public support }\end{array}$ \\
\hline & $\begin{array}{l}\text { Long term } \\
\text { PPA }\end{array}$ & $17 \%$ & Conventional CRE projects & -Identifying viable sites \\
\hline & & & & Lack of of viability of existing business model \\
\hline \multirow{4}{*}{ Self-Supply } & $\begin{array}{l}\text { Energy } \\
\text { Service } \\
\text { Companies } \\
\text { (ESCo) }\end{array}$ & $11 \%$ & $\begin{array}{l}\text { Local Authorities and potentially } \\
\text { suitable for large CRE groups }\end{array}$ & $\begin{array}{l}\text {-Not suitable for all CRE projects } \\
\text {-Very complex to coordinate } \\
\text {-Lack of resources } \\
\text {-High capital investment } \\
\text { Requires a licence or private network to } \\
\text { supply electricity }\end{array}$ \\
\hline & $\begin{array}{l}\text { Local } \\
\text { aggregation }\end{array}$ & $12 \%$ & $\begin{array}{l}\text { Large CRE groups, local } \\
\text { authorities and potentially small } \\
\text { CRE groups }\end{array}$ & $\begin{array}{l}\text {-Require smart meter } \\
\text {-Bureaucracy complexity }\end{array}$ \\
\hline & $\begin{array}{c}\text { Private } \\
\text { arrangement }\end{array}$ & $12 \%$ & Conventional CRE & $\begin{array}{l}\text {-Can be challenging to find the right customer } \\
\text {-High capital investment } \\
\text {-Requires guarantee that demand will remain } \\
\text { over lifetime of generation plant }\end{array}$ \\
\hline & $\begin{array}{l}\text { Generation } \\
\text { with storage }\end{array}$ & $20 \%$ & Some Conventional CRE & $\begin{array}{l}\text {-Lack of resource } \\
\text {-High capital investment } \\
\text {-Lack of public awareness } \\
\text {-Difficulty in raising capital } \\
\text {-Lack of established business model }\end{array}$ \\
\hline
\end{tabular}

The direct supply model has proven to be successful in other European countries, like Germany, but in the UK at the moment its introduction is formidably complex (Simpson, 2013). There is a strong case for arguing that this situation should be amended, and the UK's renewable energy schemes enabled to sell their electricity directly to local customers. This would require the UK government facilitating grid access and reducing connection charges for community-owned renewable energy. As a result, many CRE projects could potentially remain viable under the new policy regime and avoid the 'cliff edge' that currently threatens their future activity. One form of direct supply that could be considered is the 'pool and sleeve' model, which aims to aggregate localised energy production (pooling) and supply it to a specific end user without involving further wholesale market intermediaries (sleeving) (Hall and Roelich, 2016). Licence Lite suppliers provide a direct supply of 
electricity to local customers, without having to involve a third party, hopefully encouraging more participation and involvement in community-based projects. However, this approach is yet to be properly put into practice (Scown and Regen Sw, 2016). The Greater London Authority (GLA) is one the example of the Licence Lite model and due to complex conditions, this is still under development. Nevertheless, if its implementation were simplified, this model could provide an easy and reliable route for CRE projects to develop in the future, not only in London but throughout the UK (Simpson, 2013; Hall and Roelich, 2016).

The next most popular approach was that of renewable energy generation alongside battery storage. This was supported by $20 \%$ of respondents. Storage can greatly widen the utilisation opportunities for renewable energy, as well as increasing grid reliability and customer flexibility. Furthermore, it can benefit from a variety of revenue streams, such as grid flexibility and demand side services. This study has found that some CRE groups are already in the process of developing battery storage projects. There are, however, some regulation complexities and technical barriers involved in developing projects with this type of model as they will require large capital investment due to the high cost of batteries, and therefore this may not be a replicable option for all conventional CRE projects. Further to this, since public awareness surrounding the advantages of battery storage and other decentralised technologies limited, raising capital through community share would be challenging.

$12 \%$ of respondents recommended private wire arrangement; in fact, two respondents reported that planning for this was already underway. A private wire arrangement model enables decentralised energy projects to sell their electricity directly to commercial or domestic customers without the need to transmit through a public network (Hall and Roelich, 2015). A few examples of it are already operating in the UK, such as the one run by Woking Borough Council (Energy Saving Trust, 2008). However, this model can prove very challenging for voluntary-based community energy organisations due to the significant capital investment required for cabling, the need to identify suitable customers, and the legal complexity.

$11 \%$ of respondents suggested that Energy Service Companies (ESCos) could help support the future development of localised energy generation. As an ESCo model would require a licence or private wire network to supply electricity, and would be particularly suitable for local authorities and large CRE groups (10:10 Climate Action, 2016; RegenSW and Scown, 2016).

$12 \%$ of respondents felt that local aggregation and demand side response models could encourage future development. Such models would certainly be appropriate for large community energy projects and local 
authorities, but could potentially be adapted for small community energy organisations too. There have been a few trial of this model in the UK, with one being the Sunshine Tariff which was not successful under current (2016) UK legislation (RegenSW and Scown, 2016). The main challenge they face is handling customer service satisfactorily due to the complexity involved in switching energy supplier.

\section{Conclusion and recommendations}

The UK's community energy sector has seen significant growth in recent years, particularly in the number of solar PV projects. Although the sector has been supported by the government via different public subsidies and grants, this support has clearly not been consistent, and recent policy uncertainty has been extremely disadvantageous to many CRE projects, especially solar PV schemes. As community energy projects are not broadly diffused in the UK, they are very vulnerable to change in government policy (Nolden, 2013a; Seyfang et al, 2013).

Our survey provides robust evidence of the serious challenges now facing the CRE sector due to the recent curtailment in renewable energy support mechanisms. Some projects have failed completely, and of the groups that are currently active, only a few larger organisations are experimenting with innovative models; most are focused on surviving rather than developing.

\subsection{Implications for policy maker}

The UK government could still assist CRE groups to be part of the UK's energy transition by providing strategic support to facilitate networking and partnering activities among these groups. Such support could help them to reduce investment risk and overcome market barriers. The government could also help CRE groups to develop alternative business models by offering training and promoting partnerships with intermediary organisations.

Based on current regulations and available revenue streams, it would seem that the business model of renewable energy generation alongside battery storage be the most promising alternative for many of the CRE groups that are currently struggling. CRE projects existing business model relies heavily on public subsidies, which it seems the political climate in the UK no longer favours. Furthermore, much of the electricity they generate has to be exported into the national grid, which is much less cost effective than local consumption. Integrating renewable energy with electricity storage could address both these weaknesses and restore financial viability.

However, this type of model requires more technical and business expertise than existing CRE projects based on a low-risk FIT model. One of the main internal barriers to its adoption, therefore, is the comparative inexperience of the volunteers who run most CRE groups. This is where partnership with intermediary 
organisations and greater cooperation between CRE groups could be a great advantage.

Provided the deficit in their current know-how is addressed, the adoption of battery storage by CRE groups could catalyse vital innovation in the UK electricity market as a whole and provide the economic stimulus for a whole new generation of CRE projects.

\section{Acknowledgements}

We would like to thank all of our survey respondents, for without them, this research would not have been possible. Also, we are grateful to Dr. Mahtab Akhvan-Farcshchi who supported us at the early stage of this study.

\section{References}

10:10 (2016) 'Community energy The way forward'. Available at : https://1010 uk.org/articles/communityenergy-way-forward 10:10 Climate Action (2016) Community energy The way forward. Available at: https://1010uk.org/articles/community-energy-way-forward.

Allen, J., Sheate, W. R. and Diaz-Chavez, R. (2012) 'Community-based renewable energy in the Lake District National Park - local drivers, enablers, barriers and solutions', Local Environment, 17(March 2015), pp. 261280. doi: 10.1080/13549839.2012.665855.

Aslani, A. and Mohaghar, A. (2013) 'Business structure in renewable energy industry: Key areas', Renewable and Sustainable Energy Reviews, 27, pp. 569-575. doi: 10.1016/j.rser.2013.07.021.

Asmus, P. (2008) 'Exploring New Models of Solar Energy Development', The Electricity Journal, 21(3), pp. 61-70. doi: 10.1016/j.tej.2008.03.005.

Bidmon, C. and Knab, S. (2014) The Three Roles of Business Models for Socio. The XXV ISPIM Conference. Available at:

https://www.researchgate.net/publication/263065156_The_Three_Roles_of_Business_Models_for_Socio-

Technical_Transitions.

Bolinger, M. (2001) Community Wind Power Ownership Schemes in Europe and their Relevance to the United States. Available at: http://eetd.lbl.gov/EA/EMP/.

Bridge, E. and Fenna, G. (2015) Community Energy : Generating More than Renewable Energy For Community Energy England. Available at:

https://communityenergyengland.org/files/document/40/1494515981_CEE-Survey-2015-Summary.pdf. 
Catney, P., MacGregor, S., Dobson, A., Hall, S. M., Royston, S., Robinson, Z., Ormerod, M., Ross, S. and Environment, L. (2013) 'Big society, little justice? Community renewable energy and the politics of localism', Local Environment, (March 2015), pp. 1-16. doi: 10.1080/13549839.2013.792044. Centre for Sustainable Energy (2014) Urban Community Energy Fund (UCEF), Centre for Sustainable Energy. Available at: https://www.cse.org.uk/projects/view/1249 (Accessed: 10 October 2014). DECC (2014a) Community energy in the UK: Part 2: Final report, Decc. Available at: https://www.gov.uk/government/uploads/system/uploads/attachment_data/file/274571/Community_Energy_i n_the_UK_part_2_.pdf.

DECC (2014b) Community Energy Strategy : Full Report. Available at:

tps://www.gov.uk/government/uploads/system/uploads/attachment_data/file/275163/20140126Community_E nergy_Strategy.pdf.

DECC (2015a) 'Changes to renewables subsidies'. Available at:

https://www.gov.uk/government/news/changes-to-renewables-subsidies.

DECC (2015b) Community Energy Strategy Update. Available at:

https://www.gov.uk/government/uploads/system/uploads/attachment_data/file/275163/20140126Community_ Energy_Strategy.pdf.

DECC (2015c) FIT Contract For Difference Standard Terms and Conditions. Available at:

https://lowcarboncontracts.uk/sites/default/files/FINAL_CFD_Standard_Terms_and_Conditions_V2-

_13_March_2017_0.pdf.

DECC (2015d) Green Deal Finance Company funding to end, GOV.UK Press release. doi: 10.1111/j.15231739.2008.01128.x.

DECC (2015e) Review of the Feed-in Tariffs. Available at:

https://www.gov.uk/government/uploads/system/uploads/attachment_data/file/487300/FITs_Review_Govt_rr esponse_Final.pdf.

Department for Environment Food and Rural Affairs (2012) 'Rural Community Renewable Energy Fund Main points Q . Who will manage the Loan Fund? Q . If a project fails, will the community need to repay the', pp. 2011-2013.

Energy Saving Trust (2008) Woking Borough Council Joint Venture Project. Available at:

https://www.woking.gov.uk/environment/climatechange/Greeninitiatives/sustainablewoking/jointv (Accessed: 13 July 2017).

Energy Saving Trust (2012) Local Energy Assessment Fund. Available at: http://www.greencommunitiescc.org.uk/DECCFunded.aspx (Accessed: 15 April 2015). 
Environmental Audit Committee (2015) The future of the Green Investment Bank - Speeches -. Available at: https://www.gov.uk/government/speeches/the-future-of-the-green-investment-bank (Accessed: 26 June 2016). Gill Seyfang and Adrian Smith (2013) 'COMMUNITY ACTION: A NEGLECTED SITE OF INNOVATION FOR SUSTAINABLE DEVELOPMENT?', Journal of Chemical Information and Modeling, 53(9), pp. 16891699. doi: 10.1017/CBO9781107415324.004.

Gov.Wales (2014) 'Welsh Government_Evaluation of Ynni'r Fro'.

Gubbins, N. (2010) The role of community energy schemes in supporting community resilience. Available at: www.jrf.org.uk/sites/files/jrf/role-of-community-energy-schemes.pdf.

Haggett, C., Aitken, M., Harnmeijer, J., Markantoni, M., Rudolph, D. and Van Veelen, B. (2014) Supporting Community Investment in Commercial Renewable Energy Schemes Final Report, Climate Xchange Report. Available at: https://www.climatexchange.org.uk/media/1548/supporting_community_investment_in_commerical_energy_ schemes.pdf.

Haggett, C. and Aitken, M. (2015) 'Grassroots Energy Innovations: the Role of Community Ownership and Investment', Current Sustainable/Renewable Energy Reports, 2(3), pp. 98-104. doi: 10.1007/s40518-0150035-8.

Hall, D. S. and Roelich, D. K. (2015) Local Electricity Supply: Opportunities, archetypes and outcomes. Available at: https://research.ncl.ac.uk/ibuild/outputs/local_electricity_supply_report_WEB.pdf.

Hall, S. and Roelich, K. (2016) 'Business model innovation in electricity supply markets: The role of complex value in the United Kingdom', Energy Policy, 92, pp. 286-298. doi: 10.1016/j.enpol.2016.02.019.

Harnmeijer, A. L. (2016) ‘A Short History of Community Renewable Energy in the United Kingdom’, in. Available at:

tps://www.researchgate.net/publication/304571086_A_Short_History_of_Community_Renewable_Energy_in _the_United_Kingdom_characterisation_and_development_from_1870-2015.

Herbes, C., Brummer, V., Rognli, J., Blazejewski, S. and Gericke, N. (2017) 'Responding to policy change : New business models for renewable energy cooperatives - Barriers perceived by cooperatives ' members', Energy Policy, 109(June), pp. 82-95. doi: 10.1016/j.enpol.2017.06.051.

Hielscher, S. (2011) Community Energy in the UK, A Review of the Research Literature. Available at: https://grassrootsinnovations.files.wordpress.com/2012/03/cise-literature-review.pdf.

Hielscher, S., Seyfang, G. and and Smith, A. (2010) Community Innovation for Sustainable Energy. Available at: http://grassrootsinnovations.org/2012/03/24/gi-briefing-3/. 
HM Government (2009) Five point plan The UK Government has a five point plan. Available at: https://assets.publishing.service.gov.uk/government/uploads/system/uploads/attachment_data/file/228752/978 0108508394.pdf.

HM Revenue and Customs (2015) Income tax and capital gains tax : changes to Venture Capital Schemes for companies and community organisations benefiting from energy subsidies. Available at:

https://assets.publishing.service.gov.uk/government/uploads/system/uploads/attachment_data/file/385147/Ven ture_Capital_Schemes.pdf.

Huijben, J. C. C. M. and Verbong, G. P. J. (2013) ‘Breakthrough without subsidies? PV business model experiments in the Netherlands', Energy Policy, 56(January 2012), pp. 362-370. doi: 10.1016/j.enpol.2012.12.073.

Johnson, V. and Hall, S. (2014) 'Community energy and equity: The distributional implications of a transition to a decentralised electricity system', People, Place and Policy People, Place and Policy Journal Compilation, 8(83), pp. 149-167. doi: 10.3351/ppp.0008.0003.0002.

Johnson, M. W. and Suskewicz, J. (2009) 'How to Jump-Start the Clean Tech Economy.', Harvard Business Review, 87(November), pp. 52-60. doi: 10.1038/scientificamericanearth0309-22.

Martiskainen, M. (2014) Developing Community Energy Projects : experiences from Finland and the UK. University of Sussex. Available at: http://sro.sussex.ac.uk/51506/.

Nolden, C. (2013a) 'Governing community energy-Feed-in tariffs and the development of community wind energy schemes in the United Kingdom and Germany', Energy Policy, 63, pp. 543-552. doi: 10.1016/j.enpol.2013.08.050.

Nolden, C. (2013b) Regulating the diffusion of renewable energy technologies: interactions between community energy and the feed-in tariff in the UK. University of Exeter. Available at: http://ethos.bl.uk/OrderDetails.do?uin=uk.bl.ethos.579976.

Nolden, C. (2015) Performance and Impact of the Feed-in Tariff Scheme: Review of Evidence. Available at: https://assets.publishing.service.gov.uk/government/uploads/system/uploads/attachment_data/file/456181/FIT _Evidence_Review.pdf.

Ofgem (2016) Benefits for communities and schools_ Ofgem. Available at:

https://www.ofgem.gov.uk/environmental-programmes/fit/applicants/benefits-communities-and-schools (Accessed: 11 October 2017).

Osterwalder, A., Pigneur, Y. and Tucci, C. . (2005) 'Clarifying Business Models : Origins , Present, and Future of the Concept', (January 2014).

Osterwalder, A. (2004) ‘the Business Model Ontology a Proposition in a Design Science Approach'. doi: 


\subsection{7/CBO9781107415324.004.}

RegenSW and Scown, S. (2016) 'Local Supply: Options for Selling Your Energy Locally', (June). Available at: s://www.regensw.co.uk/7283018298372873/wp-content/uploads/2015/06/Regen-White.

Richter, M. (2011) 'Business model innovation for sustainable energy : German utilities and renewable energy', Centre for Sustainability Management (CSM) Leuphana Universität Lüneburg, pp. 1-29. Available at:

http://www2.leuphana.de/umanagement/csm/content/nama/downloads/download_publikationen/Richter_Busi ness Model Innovation for Sustainable Energy Ge.

Richter, M. (2013) 'German utilities and distributed PV : How to overcome barriers to business model innovation', Renewable Energy, 55, pp. 456-466. doi: 10.1016/j.renene.2012.12.052.

Rogers, J.C., Simmons, E.A., Convery, I. and Weatherall, A. (2008) 'Public perceptions of opportunities for community-based renewable energy projects', Energy Policy, 36(11), pp. 4217-4226. doi:

10.1016/j.enpol.2008.07.028.

Schneider, S. and Spieth, P. (2013) 'Business Model Innovation : towards an integrated future research agenda', International Journal of Innovation Management, (February). doi: 10.1142/S136391961340001X. Seyfang, G., Park, J. J. and Smith, A. (2013) 'A thousand flowers blooming? An examination of community energy in the UK', Energy Policy, 61, pp. 977-989. doi: 10.1016/j.enpol.2013.06.030.

Seyfang, G. and Smith, A. (2007) 'Grassroots Innovations for sustainable development: Towards a new research and policy agenda', Environmental Politics, 16(4), pp. 37-41. doi: 10.1080/09644010701419121. Simpson, A. (2013) Community Energy Strategy : DECC consultation. Available at: http://www.communityenvironment.org.uk/cms/wp-content/uploads/2013/08/Community-owned-energygeneration-Alan-Simpson.pdf.

Stamford, M. C. R. (2004) Community ownership : the best way forward for UK Wind Power?, Master Thesis. University of East Anglia. Available at: https://www.uea.ac.uk/documents/541248/10797368/Stamford+Mike.pdf/ff325ef5-cf99-465f-8420$29606 \mathrm{~b} 7 \mathrm{e} 686 \mathrm{c}$.

Strupeit, L. and Palm, A. (2015) 'Overcoming barriers to renewable energy diffusion : Business models for customer-sited solar photovoltaics in Japan, Germany and the United States', Journal of Cleaner Production. doi: 10.1016/j.jclepro.2015.06.120.

Tang, T., Karhu, K. and Hämäläinen, M. (2011) ‘Community Innovation in Sustainable Development: A Cross Case Study’, International Journal of Social, Behavioral, Educational, Economic, Business and 
Industrial Engineering, 73(1), pp. 396-403.

Walker, G. (2008) 'What are the barriers and incentives for community-owned means of energy production and use?', Energy Policy, 36, pp. 4401-4405. doi: 10.1016/j.enpol.2008.09.032.

Walker, G. and Devine-Wright, P. (2008) ‘Community renewable energy: What should it mean?', Energy Policy, 36(2), pp. 497-500. doi: 10.1016/j.enpol.2007.10.019.

Walker, G., Hunter, S., Devine-Wright, P., Evans, B. and Fay, H. (2007) 'Harnessing community energiesexplaining community based localism in renewable energy policy in the UK', Global Environmental Politics, pp. 64-84.

Willis, R. and Willis, J. (2012) Co-operative renewable energy in the UK a guide to this growing sector, The co-operative UK. Available at: https://www.uk.coop/resources/co-operative-renewable-energy-uk-guidegrowing-sector. 